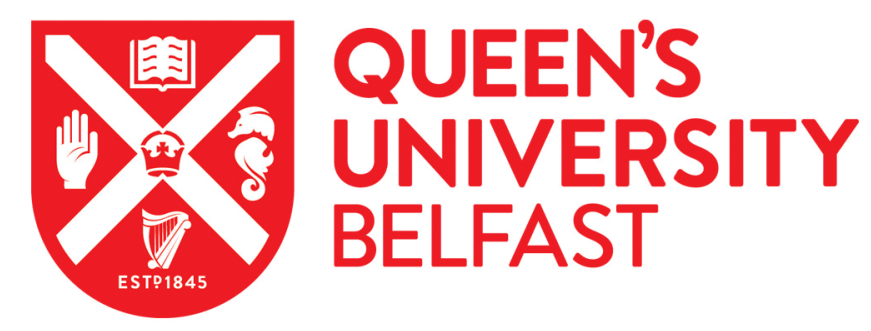

\title{
Tolerance of grasses to heavy metals and microbial functional diversity in soils contaminated with copper mine tailings
}

Teng, Y., Luo, Y. M., Huang, C. Y., Long, J., Li, Z. G., \& Christie, P. (2008). Tolerance of grasses to heavy metals and microbial functional diversity in soils contaminated with copper mine tailings. Pedosphere, 18(3), 363-370. https://doi.org/10.1016/S1002-0160(08)60026-0

Published in:

Pedosphere

Queen's University Belfast - Research Portal:

Link to publication record in Queen's University Belfast Research Portal

\section{General rights}

Copyright for the publications made accessible via the Queen's University Belfast Research Portal is retained by the author(s) and / or other copyright owners and it is a condition of accessing these publications that users recognise and abide by the legal requirements associated with these rights.

Take down policy

The Research Portal is Queen's institutional repository that provides access to Queen's research output. Every effort has been made to ensure that content in the Research Portal does not infringe any person's rights, or applicable UK laws. If you discover content in the Research Portal that you believe breaches copyright or violates any law, please contact openaccess@qub.ac.uk. 


\title{
Tolerance of Grasses to Heavy Metals and Microbial Functional Diversity in Soils Contaminated with Copper Mine Tailings ${ }^{* 1}$
}

\author{
TENG Ying ${ }^{1,2}$, LUO Yong-Ming ${ }^{1, * 2}$, HUANG Chang-Yong ${ }^{2}$, LONG Jian $^{2}$, LI Zhen-Gao $^{1}$ and \\ P. CHRISTIE ${ }^{3}$ \\ ${ }^{1}$ Soil and Environment Bioremediation Research Centre, Institute of Soil Science, Chinese Academy of Sciences, Nanjing \\ 210008 (China).E-mail: yteng@issas.ac.cn \\ ${ }^{2}$ College of Resources and Environmental Sciences, Zhejiang University, Hangzhou 310029 (China) \\ ${ }^{3}$ Department of Agricultural and Environmental Science, Queen's University Belfast, Newforge Lane, Belfast BT9 5PX \\ (UK)
}

(Received July 26, 2007; revised March 20, 2008)

\begin{abstract}
Copper $(\mathrm{Cu})$ mine tailings, because of their high content of heavy metals, are usually hostile to plant colonization. A pot experiment was conducted to determine the tolerance of four forage grasses to heavy metals in $\mathrm{Cu}$ mine tailings and to examine the variation in the microbial functional diversity of soils from the tailing sites in southern China. All the four grass species survived on $\mathrm{Cu}$ mine tailings and $\mathrm{Cu}$ mine tailing-soil mixture. However, on pure mine tailings, the growth was minimal, whereas the growth was maximum for the control without mine tailings. The tolerance of grasses to heavy metals followed the sequence: Paspalum notatum $>$ Festuca arundinacea $>$ Lolium perenne $>$ Cynodon dactylon. The planting of forage grasses enhanced the soil microbial biomass. The Biolog data indicated that the soil microbial metabolic profile values (average well color development, community richness, and Shannon index) of the four forage grasses also followed the sequence: $P$. notatum $>F$. arundinacea $>$ L. perenne $>$ C. dactylon. Thus, P. notatum, under the experimental conditions of this study, may be considered as the preferred plant species for revegetation of $\mathrm{Cu}$ mine tailing areas.
\end{abstract}

Key Words: copper mine tailings, forage grass, heavy metal pollution, microbial functional diversity

Citation: Teng, Y., Luo, Y. M., Huang, C. Y., Long, J., Li, Z. G. and Christie, P. 2008. Tolerance of grasses to heavy metals and microbial functional diversity in soils contaminated with copper mine tailings. Pedosphere. 18(3): 363-370.

\section{INTRODUCTION}

Mining is one of the most important sources for procuring heavy metals from the environment. Metalliferous mine tailing ponds are of environmental concern because of the potential hazards of surface or groundwater pollution, offsite contamination by wind-transported materials, the redistribution of the contaminated soils, and the uptake by vegetation and bioaccumulation in food chains (Lan et al., 1998). Large areas of agricultural land can be contaminated. There are several metalliferous mines to the south of the Yangtze River in China, which has had a long history of metalliferous mining. Mining was most extensive during the early 20th century. Subsequently, most of the mines were abandoned because of the exhaustion of metal ores. However, these abandoned mines can become an important point source of potentially toxic elements, such as $\mathrm{Cu}, \mathrm{Pb}, \mathrm{Zn}, \mathrm{As}$, and $\mathrm{Cd}$, and can contaminate the soil environment. Owing to the high concentrations of potentially toxic heavy metals, low concentrations of plant nutrients, poor substrate physical structure, and extremes of $\mathrm{pH}$ (Lan and Shu, 1996), most plants have difficulty growing in tailings. Thus, areas that are contaminated by mining tailings received less attention from the point of view of environmental monitoring and ecological restoration.

\footnotetext{
${ }^{* 1}$ Project supported by the National Natural Sciences Foundation of China (Nos. 40171054 and 40125005) and the National Key Basic Research Support Foundation of China (No. 2002CB410809/10).

${ }^{* 2}$ Corresponding author. E-mail: ymluo@issas.ac.cn
} 
Several studies have been conducted in various countries on the trace element contamination due to mining activities in soils and on the ecological restoration and amelioration of tailing-contaminated soils (Jung and Thornton, 1996; Lan and Shu, 1996; Tu et al., 2000; Zhang et al., 2001; Ye et al., 2002; Wong, 2003). Soil microorganisms are known to be sensitive to changes in the soil environment (Liu et al., 2005; Zhao, 2006). Nevertheless, there have been few studies on the effects of microorganisms on soil-plant systems. In fact, when restoring areas contaminated with metalliferous mine tailings, ideally, both the vegetation cover and the soil microbial community should be taken into account. Therefore, in mine tailing areas, rebuilding the soil microbial communities is an important task for restoring environmental quality.

In this study, four forage grasses were grown in pots filled with soil that was polluted by mine tailings. The main objectives of this study were to investigate the tolerance of four varieties of forage grasses to heavy metal pollution in soils affected by copper mining activity, to examine the variation in the microbial characteristics of soils throughout the growth stage of the grasses, and to provide a scientific basis for the prevention and remediation of heavy metal pollution and the reclamation of the abandoned metalliferous mine sites in southern China.

\section{MATERIALS AND METHODS}

Mine tailings were collected from the top $20 \mathrm{~cm}$ of an abandoned $\mathrm{Cu}$ mine site at Lipu Town, Zhuji City, Zhejiang Province, southern China. Samples of a yellow soil were collected from the top $20 \mathrm{~cm}$ of a nonpolluted site, $1.5 \mathrm{~km}$ away from the mine area. All samples were air-dried and passed through a 2-mm mesh sieve. Seeds of the forage grasses Paspalum notatum, Lolium perenne, Cynodon dactylon, and Festuca arundinacea were obtained from the Zhejiang Hongyun Grass Industry Corporation.

A pot experiment was conducted in a glasshouse at Zhejiang University. The experimental design was a randomized complete block with five treatments in triplicate. The five treatments included $100 \%$ mine tailings (A), $75 \%$ mine tailing $+25 \%$ soil (B), $50 \%$ mine tailings $+50 \%$ soil (C), $25 \%$ mine tailings $+75 \%$ soil (D), and $100 \%$ soil (E, control). After mixed thoroughly, all the samples $2 \mathrm{~kg}$ each were transferred to plastic pots of $15 \mathrm{~cm} \times 19 \mathrm{~cm}$ size together with basal $\mathrm{N}, \mathrm{P}$, and $\mathrm{K}$ fertilizers. The N, P,

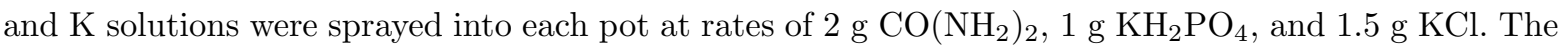
soil moisture was adjusted to $45 \%$ water holding capacity (WHC) before sowing the grass seeds. After the seeds were sown on April 25, 2002, the soil moisture during the plant growth was maintained at $45 \%$ WHC using deionized water. On July 25, 2002, the aboveground parts of the plants were harvested, and the weight and height of the plants were measured. The plant samples were washed with distilled water, dried at $65{ }^{\circ} \mathrm{C}$ to a constant dry weight, and ground in a stainless steel mill before analysis. The plant biomass of the mine tailings treatments (A, B, C, D) and that of the control (E) were determined and ratios between them were calculated as the tolerance index of the biomass of the four forage grasses. After harvest, $500 \mathrm{~g}$ of soil was sampled from each pot, air-dried, and passed through a 2-mm mesh sieve for heavy metal analysis. At the same time, fresh soil samples were collected and incubated for 7 days at $25^{\circ} \mathrm{C}$ after large pieces of plant roots were removed, and the soil moisture was adjusted to $45 \%$ WHC before measuring the soil microbial biomass and community functional diversity.

Some physicochemical properties and heavy metal concentrations in the mixtures with different percentages of mine tailings (Table I) and the plant samples were analyzed as follows. $\mathrm{pH}$ (soil/ $\mathrm{H}_{2} \mathrm{O}$ ratio $=1: 2$ ) was measured using a $\mathrm{pH}$ meter with a glass electrode. Organic $\mathrm{C}$ and total $\mathrm{N}$ were determined by dichromate oxidation and Kjeldahl digestion-distillation, respectively (Nelson and Sommers, 1982; Bremner and Mulvaney, 1982). After the samples were digested with concentrated $\mathrm{HCl}-\mathrm{HNO}_{3}-\mathrm{HClO}_{4}-$ $\mathrm{HF}, \mathrm{Cu}, \mathrm{Zn}, \mathrm{Pb}$, and $\mathrm{Cd}$ were determined using atomic absorption spectrophotometry. The available metals were extracted with $0.5 \mathrm{mmol} \mathrm{L}^{-1} \mathrm{HCl}$ solution and were determined using atomic absorption spectrophotometry $(\mathrm{Lu}, 1999)$. The plant samples were subjected to dry ashing at $550{ }^{\circ} \mathrm{C}$ for $6 \mathrm{~h}$, dissolved in $2 \mathrm{~mol} \mathrm{~L}^{-1}$ diluted $\mathrm{HCl}$ solution, and analyzed for heavy metal contents using atomic absorption spectrophotometry. 
TABLE I

Some physicochemical properties and heavy metal concentrations of the mixtures in the treatments with different proportions of mine tailings

\begin{tabular}{|c|c|c|c|c|c|c|c|c|c|c|c|}
\hline \multirow[t]{2}{*}{ Treatment $^{\mathrm{a})}$} & \multirow{2}{*}{$\begin{array}{l}\mathrm{pH} \\
\left(\mathrm{H}_{2} \mathrm{O}\right)\end{array}$} & \multirow{2}{*}{$\begin{array}{l}\text { Organic } \\
\mathrm{C}\end{array}$} & \multirow{2}{*}{$\begin{array}{l}\text { Total } \\
\mathrm{N}\end{array}$} & \multicolumn{4}{|c|}{ Total heavy metal } & \multicolumn{4}{|c|}{ Available heavy metal } \\
\hline & & & & $\mathrm{Cu}$ & $\mathrm{Zn}$ & $\mathrm{Pb}$ & $\mathrm{Cd}$ & $\mathrm{Cu}$ & $\mathrm{Zn}$ & $\mathrm{Pb}$ & $\mathrm{Cd}$ \\
\hline & & \multicolumn{2}{|c|}{$\mathrm{g} \mathrm{kg}^{-1}$} & & & & \multicolumn{5}{|c|}{$\mathrm{mg} \mathrm{kg}^{-1}$} \\
\hline A & 4.8 & 6.7 & 0.98 & 1626.0 & 11060.0 & 2534.0 & 56.13 & 282.3 & 644.8 & 487.7 & 5.44 \\
\hline B & 4.9 & 12.5 & 1.08 & 986.5 & 7869.0 & 2131.0 & 38.96 & 198.4 & 521.7 & 326.9 & 2.85 \\
\hline C & 5.3 & 13.6 & 1.25 & 675.8 & 5321.0 & 1627.0 & 24.19 & 153.8 & 405.7 & 250.2 & 1.16 \\
\hline D & 5.5 & 14.6 & 1.38 & 234.8 & 1756.0 & 327.9 & 12.05 & 74.2 & 212.1 & 136.0 & 0.15 \\
\hline $\mathrm{E}$ & 5.8 & 14.9 & 1.51 & 41.6 & 72.3 & 37.3 & 0.58 & 10.5 & 58.2 & 7.9 & 0.03 \\
\hline
\end{tabular}

a) $\mathrm{A}=100 \%$ mine tailings, $\mathrm{B}=75 \%$ mine tailing $+25 \%$ soil, $\mathrm{C}=50 \%$ mine tailings $+50 \%$ soil, $\mathrm{D}=25 \%$ mine tailings $+75 \%$ soil, $\mathrm{E}=100 \%$ soil (control).

The soil microbial biomass $\mathrm{C}$ was estimated using the fumigation-extraction method (Vance et al., 1987). Chloroform fumigation was carried out with ethanol-free $\mathrm{CHCl}_{3}$ for $24 \mathrm{~h}$ at $25{ }^{\circ} \mathrm{C}$ in dark. After the $\mathrm{CHCl}_{3}$ was removed, the soil samples were extracted by shaking with $50 \mathrm{~mL}$ of $0.5 \mathrm{mmol} \mathrm{L}-1$ $\mathrm{K}_{2} \mathrm{SO}_{4}$ for 30 min on a rotary shaker. The suspensions were then filtered through Whatman No. 42 filter paper. The triplicate subsamples of the unfumigated control were extracted in the same manner and at the same time as were the fumigated samples. The soil microbial biomass $\mathrm{C}$ in the soil extracts was determined using an automated TOC Analyser (Shimadzu, TOC-500, Japan), and a $K_{\mathrm{EC}}$ (extractable part of microbial biomass C) of 0.45 was used to convert the measured flush of $\mathrm{C}$ to biomass $\mathrm{C}$ (Yao et al., 2003).

Sole carbon source utilization tests were performed as described by Campbell et al. (1997) and Yao et al. (2000). Briefly, $10 \mathrm{~g}$ of fresh soil was added to $100 \mathrm{~mL}$ of distilled water in a $250-\mathrm{mL}$ flask and was shaken for $10 \mathrm{~min}$. Ten-fold serial dilutions were prepared, and the $10^{-3}$ dilution was used to inoculate the Biolog GN 96-well microtiter plates. The plates were incubated at $25{ }^{\circ} \mathrm{C}$ for 7 days and the color development was measured as absorbance $(A)$ using an automated plate reader (VMAX, Molecular Devices, Crawley, UK) at $590 \mathrm{~nm}$. The data were collected using the Microlog 4.01 software (Biolog, Hayward, CA, USA). The plates were read twice daily, and ANOVA (analysis of variance) of the average well color development (AWCD) with time was used to select the comparable time points to avoid confounding effects of differences in the inoculum density between the treatments in the multivariate analysis (Garland, 1997). The AWCD for the 95 carbon sources was calculated as a measure of the total activity. AWCD and the Shannon index were calculated for each reading of the microtiter plates. AWCD was calculated as the arithmetic average of the absorbance values for all the carbon sources. The Shannon index $(H)$ was calculated using the following equation:

$H=-\Sigma p_{i} \ln p_{i}$

where $p_{i}$ is the ratio of the absorbance value of the $i$ well to that of the whole plate. The reactive well numbers of the metabolic profiles expressed the richness of the soil microbial community $(S)$.

Statistical testing was performed using a single-factor ANOVA followed by mean separation with Tukey's test. For multivariate analysis of the Biolog data, the absorbance values were first transformed by dividing them by the AWCD values to avoid bias between samples with different inoculum densities (Garland, 1997).

\section{RESULTS AND DISCUSSION}

\section{Tolerance index of forage grass biomass}

High heavy metal concentrations in mine tailings restricted the growth, development, and metabolic 
activities of some forage grasses, and the treatments A-D had lower biomass than the control (Fig. 1). For each treatment, there was a significant difference $(P \leq 0.05)$ in the biomass among the four forage grasses (Fig. 1). This may be attributed to the different morphological characteristics and to the difference in heavy metal tolerance of the grasses. The biomass of tall forage grass is usually greater than that of dwarf grass (Xia and Shu, 2001). Also, the higher the tolerance index, the lesser the effect of heavy metals on the plant biomass and the greater the tolerance of plants to the heavy metals (Long et al., 2003).
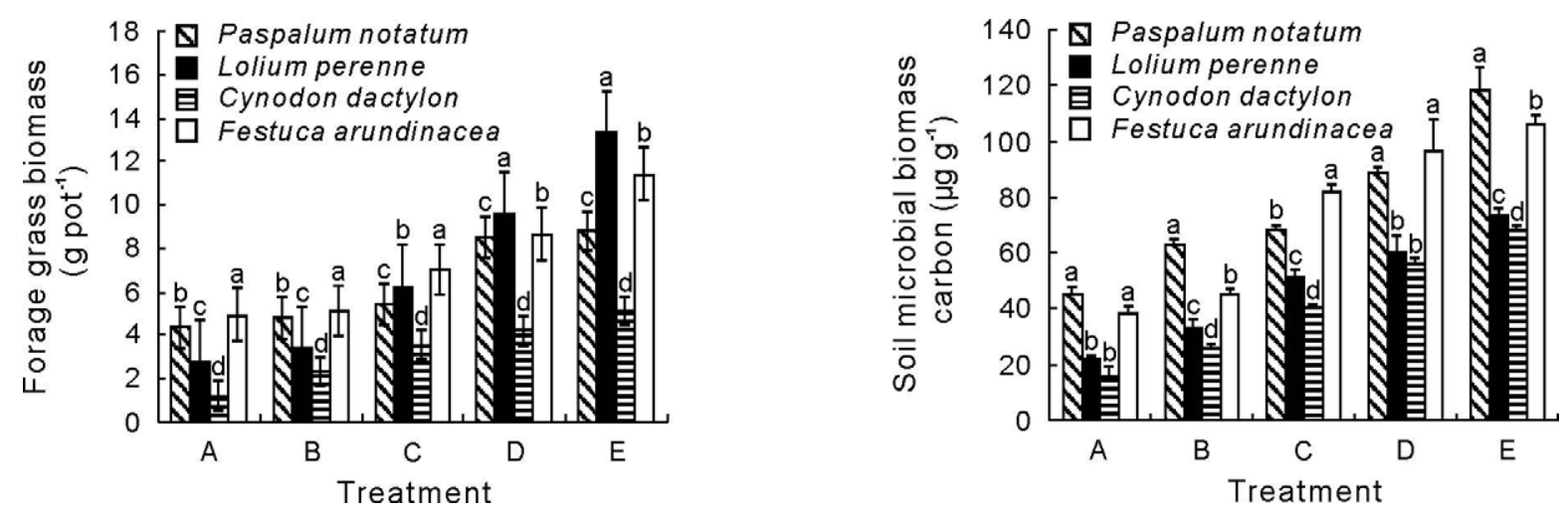

Fig. 1 Biomass of four forage grasses in the treatments having different proportions of mine tailings: $\mathrm{A}=100 \%$ mine tailings, $\mathrm{B}=75 \%$ mine tailing $+25 \%$ soil, $\mathrm{C}=50 \%$ mine tailings $+50 \%$ soil, $\mathrm{D}=25 \%$ mine tailings $+75 \%$ soil, $\mathrm{E}=$ $100 \%$ soil (control).

Fig. 2 Changes in the soil microbial biomass carbon after planting four forage grasses in the treatments containing different proportions of mine tailings: $\mathrm{A}=100 \%$ mine tailings, $\mathrm{B}=75 \%$ mine tailing $+25 \%$ soil, $\mathrm{C}=50 \%$ mine tailings $+50 \%$ soil, $\mathrm{D}=25 \%$ mine tailings $+75 \%$ soil, $\mathrm{E}=100 \%$ soil (control).

The changes in the tolerance index of the biomass for the four grasses with different proportions of mine tailings are in the order: P. notatum $>F$. arundinacea $>$ L. perenne $>$ C. dactylon (Table II). Thus, $P$. notatum showed the best growth. Moreover, the tolerance index was similar for $P$. notatum with $100 \%$ mine tailings, F. arundinacea and L. perenne with $50 \%$ mine tailings, and $C$. dactylon with $25 \%$ mine tailings, suggesting that different plant species had their own characteristic tolerance to heavy metals, which may be related to a number of recovery pathways to heavy metal toxicity produced during the process of long-term evolution of different forage grasses (Zhang and Cai, 1999).

\section{TABLE II}

Tolerance index ${ }^{\mathrm{a})}$ (mean \pm standard deviation) of the biomass of the four forage grasses in the treatments with different proportions of mine tailings

\begin{tabular}{lllll}
\hline Treatment $^{\mathrm{b})}$ & Paspalum notatum & Festuca arundinacea & Lolium perenne & Cynodon dactylon \\
\hline $\mathrm{A}$ & $0.50 \pm 0.08^{\mathrm{b})}$ & $0.35 \pm 0.06$ & $0.29 \pm 0.02$ & $0.21 \pm 0.04$ \\
$\mathrm{~B}$ & $0.75 \pm 0.05$ & $0.41 \pm 0.02$ & $0.32 \pm 0.04$ & $0.22 \pm 0.05$ \\
$\mathrm{C}$ & $0.77 \pm 0.04$ & $0.52 \pm 0.04$ & $0.51 \pm 0.03$ & $0.37 \pm 0.05$ \\
$\mathrm{D}$ & $0.97 \pm 0.05$ & $0.75 \pm 0.05$ & $0.66 \pm 0.06$ & $0.54 \pm 0.07$ \\
\hline
\end{tabular}

a) The tolerance index indicates the ratio of the biomass of treatments with the mine tailings to that of the control without mine tailings.

b) $\mathrm{A}=100 \%$ mine tailings, $\mathrm{B}=75 \%$ mine tailings $+25 \%$ soil, $\mathrm{C}=50 \%$ mine tailings $+50 \%$ soil, $\mathrm{D}=25 \%$ mine tailings $+75 \%$ soil.

\section{Heavy metal concentrations in grasses}

Heavy metal concentrations in the grasses generally increased with increasing concentration of heavy metals in the mine tailings, except for Cd in the case of F. arundinacea (Table III). With regard to the heavy metal concentration in P. notatum, a significant increase was observed in Treatment A (100\% mine 
tailings) $(P \leq 0.05)$, with $\mathrm{Cu}, \mathrm{Cd}, \mathrm{Pb}$, and $\mathrm{Zn}$ being increased by $2.5,1.6,2.4$, and 2.8 times compared with those of the control (100\% soil), respectively. The higher mine tailing levels in Treatments C, B, and $\mathrm{A}$ led to even more marked increases in $\mathrm{Cu}, \mathrm{Cd}, \mathrm{Pb}$, and $\mathrm{Zn}$ concentrations when compared with the control. The changing trends in heavy metal concentrations of the other grasses in each treatment were similar to those observed in $P$. notatum. The order of heavy metal concentrations in the grasses was: $\mathrm{Zn}>\mathrm{Pb}>\mathrm{Cu}>\mathrm{Cd}$. The changes in the heavy metal concentrations in the forage grasses were mainly attributed to the differences in the concentrations of the metals in the mine tailings (Table I).

TABLE III

Concentrations (mean \pm standard deviation) of $\mathrm{Cu}, \mathrm{Cd}, \mathrm{Pb}$, and $\mathrm{Zn}$ in the four forage grasses in the treatments containing different proportions of mine tailings

\begin{tabular}{|c|c|c|c|c|c|c|}
\hline \multirow[t]{2}{*}{ Forage grass } & \multirow[t]{2}{*}{ Heavy metal } & \multicolumn{5}{|l|}{ Treatment $^{\text {a) }}$} \\
\hline & & A & B & $\mathrm{C}$ & $\mathrm{D}$ & $\mathrm{E}$ \\
\hline & & & & $\mathrm{mg} \mathrm{kg}^{-1}$ & & \\
\hline \multirow[t]{4}{*}{ Paspalum notatum } & $\mathrm{Cu}$ & $65.3 \pm 4.5 \mathrm{a}^{\mathrm{b})}$ & $64.2 \pm 4.6 \mathrm{a}$ & $62.3 \pm 4.4 \mathrm{a}$ & $44.8 \pm 1.9 \mathrm{~b}$ & $18.2 \pm 2.3 \mathrm{c}$ \\
\hline & $\mathrm{Cd}$ & $18.1 \pm 0.8 \mathrm{a}$ & $14.9 \pm 1.4 \mathrm{~b}$ & $14.5 \pm 0.6 \mathrm{~b}$ & $6.7 \pm 0.5 \mathrm{c}$ & $4.3 \pm 0.4 \mathrm{c}$ \\
\hline & $\mathrm{Pb}$ & $217.5 \pm 12.3 \mathrm{a}$ & $209.3 \pm 6.7 \mathrm{a}$ & $135.9 \pm 16.9 \mathrm{~b}$ & $79.8 \pm 6.8 \mathrm{c}$ & $33.3 \pm 3.7 \mathrm{~d}$ \\
\hline & $\mathrm{Zn}$ & $331.6 \pm 10.6 \mathrm{a}$ & $327.6 \pm 5.4 \mathrm{a}$ & $219.2 \pm 13.9 \mathrm{~b}$ & $138.3 \pm 11.3 \mathrm{c}$ & $50.1 \pm 7.5 \mathrm{~d}$ \\
\hline \multirow[t]{4}{*}{ Festuca arundinacea } & $\mathrm{Cu}$ & $25.2 \pm 1.9 \mathrm{a}$ & $21.2 \pm 2.3 \mathrm{ab}$ & $19.6 \pm 0.9 \mathrm{~b}$ & $14.9 \pm 0.9 \mathrm{c}$ & $6.9 \pm 0.7 \mathrm{~d}$ \\
\hline & $\mathrm{Cd}$ & $7.1 \pm 0.5 \mathrm{a}$ & $6.9 \pm 0.6 \mathrm{a}$ & $6.0 \pm 0.2 \mathrm{a}$ & $3.1 \pm 0.3 \mathrm{~b}$ & $3.5 \pm 0.5 b$ \\
\hline & $\mathrm{Pb}$ & $309.5 \pm 11.8 \mathrm{a}$ & $287.3 \pm 11.3 \mathrm{a}$ & $231.6 \pm 17.6 \mathrm{~b}$ & $134.5 \pm 22.4 \mathrm{c}$ & $27.9 \pm 6.0 \mathrm{~d}$ \\
\hline & $\mathrm{Zn}$ & $380.4 \pm 16.5 \mathrm{a}$ & $326.6 \pm 12.0 \mathrm{~b}$ & $219.5 \pm 15.2 \mathrm{c}$ & $215.6 \pm 16.8 \mathrm{c}$ & $75.1 \pm 4.6 \mathrm{~d}$ \\
\hline \multirow[t]{4}{*}{ Lolium perenne } & $\mathrm{Cu}$ & $27.1 \pm 5.7 \mathrm{a}$ & $22.5 \pm 2.1 \mathrm{a}$ & $17.4 \pm 0.9 \mathrm{~b}$ & $13.2 \pm 0.8 \mathrm{c}$ & $9.3 \pm 0.6 \mathrm{~d}$ \\
\hline & $\mathrm{Cd}$ & $8.2 \pm 1.2 \mathrm{a}$ & $6.7 \pm 0.5 \mathrm{~b}$ & $4.7 \pm 0.5 \mathrm{c}$ & $2.5 \pm 0.3 \mathrm{~d}$ & $2.0 \pm 0.2 \mathrm{~d}$ \\
\hline & $\mathrm{Pb}$ & $289.9 \pm 15.8 \mathrm{a}$ & $276.8 \pm 17.5 \mathrm{ab}$ & $252.2 \pm 22.9 \mathrm{~b}$ & $125.7 \pm 19.8 \mathrm{c}$ & $19.3 \pm 4.6 \mathrm{~d}$ \\
\hline & $\mathrm{Zn}$ & $396.3 \pm 17.2 \mathrm{a}$ & $345.1 \pm 13.4 \mathrm{a}$ & $230.6 \pm 16.6 \mathrm{~b}$ & $227.4 \pm 13.1 \mathrm{~b}$ & $65.5 \pm 5.3 \mathrm{c}$ \\
\hline \multirow[t]{4}{*}{ Cynodon dactylon } & $\mathrm{Cu}$ & $23.0 \pm 3.6 \mathrm{a}$ & $18.7 \pm 3.7 \mathrm{~b}$ & $16.2 \pm 1.2 \mathrm{~b}$ & $10.8 \pm 0.7 \mathrm{c}$ & $3.2 \pm 0.7 \mathrm{~d}$ \\
\hline & $\mathrm{Cd}$ & $7.2 \pm 1.5 \mathrm{a}$ & $6.8 \pm 1.3 \mathrm{a}$ & $3.7 \pm 0.3 \mathrm{~b}$ & $2.6 \pm 0.3 \mathrm{~b}$ & $1.1 \pm 0.1 \mathrm{c}$ \\
\hline & $\mathrm{Pb}$ & $247.3 \pm 16.2 \mathrm{a}$ & $203.8 \pm 13.7 \mathrm{~b}$ & $148.5 \pm 11.2 \mathrm{c}$ & $118.4 \pm 10.3 \mathrm{~d}$ & $21.5 \pm 5.1 \mathrm{e}$ \\
\hline & $\mathrm{Zn}$ & $321.3 \pm 12.3 \mathrm{a}$ & $265.7 \pm 11.5 b$ & $237.2 \pm 16.7 \mathrm{c}$ & $179.5 \pm 21.6 \mathrm{~d}$ & $57.2 \pm 6.8 \mathrm{e}$ \\
\hline
\end{tabular}

a) $\mathrm{A}=100 \%$ mine tailings, $\mathrm{B}=75 \%$ mine tailing $+25 \%$ soil, $\mathrm{C}=50 \%$ mine tailings $+50 \%$ soil, $\mathrm{D}=25 \%$ mine tailings $+75 \%$ soil, $\mathrm{E}=100 \%$ soil (control).

b) Means in the same line followed by the same letter are not significantly different at $P \leq 0.05$.

To some extent, there were differences in the heavy metal concentrations among the four forage grasses (Table III). This result was similar to those of Tu et al. (2000) and Xia and Shu (2001) who reported that different plant types or species show different responses to heavy metals, especially the status of growth and the genetic control of development of roots.

\section{Soil microbial biomass carbon}

The soil microbial biomass carbon $\left(\mathrm{C}_{\text {mic }}\right)$ declined with the increasing mine tailing levels in the soil (Fig. 2). Treatments A to D resulted in some decrease in $\mathrm{C}_{\text {mic }}$ when compared with Treatment E (no mine tailings). Chander and Brookes (1993) reported that high concentrations of heavy metals decreased the functional diversity of the soil microbial community, affected the soil microbial population, and weakened the microbial activities. The soil microorganisms reacted to heavy metal pollution by losing their original ecological function, resulting in a reduction in soil environmental quality.

The results in Fig. 2 also show that planting different forage grasses markedly affected the soil microbial biomass in the following order: P. notatum $>F$. arundinacea $>$ L. perenne $>C$. dactylon. This may be because of the grasses decreasing the absorption of heavy metals, improving the rhizosphere microenvironment, producing copious root exudates, and inevitably increasing the soil microbial biomass. Martin and Merckx (1992) found that plant roots could release $10 \%-40 \%$ of their net total carbon into the rhizosphere. P. notatum had the strongest tolerance to heavy metals in mine tailings (Table II). This 
conclusion is in accordance with the previous result (Long et al., 2003). In addition, Cu pollution was found to be very important in $\mathrm{Cu}$ mine tailings ( $\mathrm{Tu}$ et al., 2000; Zhou et al., 2002). Thus, P. notatum may be suitable as a pioneer forage grass for the reclamation of the $\mathrm{Cu}$ mine tailing areas.

\section{Functional diversity of the soil microbial community}

The structure of the soil microbial community is considered to be a biological indicator of heavy metal stress (Doelman et al., 1994). The Biolog system uses 95 different carbon sources to produce a metabolic profile of microorganisms (Garland, 1997). The assay is based on measuring the oxidative catabolism of the substrates to generate patterns of potential sole carbon source utilization. The average well color development (AWCD) is an important and sensitive indicator reflecting the metabolic profiles of the soil microbial community, especially to toxic heavy metals in soils.

The results in Table IV show that AWCD increased with decreasing levels of mine tailings, suggesting that the quantity of carbon utilization by soil microorganisms could have increased and more carbon sources were depleted with higher heavy metal levels. AWCD was of the following order in the four grasses: P. notatum $>$ F. arundinacea $>$ L. perenne $>$ C. dactylon. This indicated that planting grasses, especially $P$. notatum, enhanced the soil microbial activities, stimulated the soil metabolic activities and the intensity of the activities, and altered the structural and functional diversity of the soil microbial community.

\section{TABLE IV}

Soil microbial community functional diversity after planting four forage grasses in the treatments containing different proportions of mine tailings

\begin{tabular}{|c|c|c|c|c|c|c|}
\hline \multirow[t]{2}{*}{ Forage grass } & \multirow[t]{2}{*}{ Indicator $^{a}$ ) } & \multicolumn{5}{|c|}{ Treatment $^{\mathrm{b})}$} \\
\hline & & A & $\mathrm{B}$ & $\mathrm{C}$ & $\mathrm{D}$ & $\mathrm{E}$ \\
\hline \multirow[t]{3}{*}{ Paspalum notatum } & AWCD & $0.15 \mathrm{~d}^{\mathrm{c})}$ & $0.22 \mathrm{c}$ & $0.30 \mathrm{~b}$ & $0.47 \mathrm{a}$ & $0.52 \mathrm{a}$ \\
\hline & $S$ & $10 \mathrm{e}$ & $25 \mathrm{~d}$ & $34 \mathrm{c}$ & $51 \mathrm{~b}$ & $75 \mathrm{a}$ \\
\hline & $H$ & $1.24 \mathrm{~d}$ & $1.41 \mathrm{c}$ & $2.25 \mathrm{~b}$ & $2.74 \mathrm{a}$ & $2.87 \mathrm{a}$ \\
\hline \multirow[t]{3}{*}{ Festuca arundinacea } & AWCD & $0.14 \mathrm{~d}$ & $0.20 \mathrm{c}$ & $0.27 \mathrm{~b}$ & $0.33 \mathrm{~b}$ & $0.45 \mathrm{a}$ \\
\hline & $S$ & $10 \mathrm{~d}$ & $23 \mathrm{c}$ & $31 \mathrm{bc}$ & $48 \mathrm{~b}$ & $68 \mathrm{a}$ \\
\hline & $H$ & $1.24 \mathrm{~d}$ & $1.37 \mathrm{c}$ & $2.21 \mathrm{~b}$ & $2.73 \mathrm{a}$ & $2.81 \mathrm{a}$ \\
\hline \multirow[t]{3}{*}{ Lolium perenne } & AWCD & $0.10 \mathrm{~d}$ & $0.15 \mathrm{c}$ & $0.18 \mathrm{c}$ & $0.23 \mathrm{~b}$ & $0.31 \mathrm{a}$ \\
\hline & $S$ & $9 \mathrm{e}$ & $14 \mathrm{~d}$ & $20 \mathrm{c}$ & $35 \mathrm{~b}$ & $53 \mathrm{a}$ \\
\hline & $H$ & $1.02 \mathrm{~d}$ & $1.35 \mathrm{c}$ & $2.10 \mathrm{~b}$ & $2.66 \mathrm{a}$ & $2.75 \mathrm{a}$ \\
\hline \multirow[t]{3}{*}{ Cynodon dactylon } & AWCD & $0.08 \mathrm{c}$ & $0.13 \mathrm{~b}$ & $0.16 \mathrm{~b}$ & $0.17 \mathrm{~b}$ & $0.22 \mathrm{a}$ \\
\hline & $S$ & $6 \mathrm{~d}$ & $11 \mathrm{c}$ & $17 \mathrm{~b}$ & $25 \mathrm{a}$ & $28 \mathrm{a}$ \\
\hline & $H$ & $0.79 \mathrm{~d}$ & $1.28 \mathrm{c}$ & $1.85 \mathrm{~b}$ & $2.53 \mathrm{a}$ & $2.68 \mathrm{a}$ \\
\hline
\end{tabular}

a) AWCD is the average well color development measured as the average absorbance values, $S$ is the richness of the microbial community, and $H$ is the Shannon index.

b) $\mathrm{A}=100 \%$ mine tailings, $\mathrm{B}=75 \%$ mine tailing $+25 \%$ soil, $\mathrm{C}=50 \%$ mine tailings $+50 \%$ soil, $\mathrm{D}=25 \%$ mine tailings $+75 \%$ soil, $\mathrm{E}=100 \%$ soil (control).

c) Means in the same line followed by the same letter are significantly different at $P \leq 0.05$.

Because microorganisms in soil polluted by mine tailings differed in their priority and selective utilization of carbon sources during the process of incubation, the color of the reaction wells in the Biolog GN plates changed to varying degrees. The degree of color change in Biolog GN plate wells indirectly reflected the differences in the structure of the soil microbial community. The more the color of the wells in the Biolog GN plates changed, the richer the soil microbial community. Thus, the extent of well color change indicated the richness of the functional diversity of the soil microbial community $(S)$.

Among the different proportions of mine tailings, there were significant differences $(P \leq 0.05)$ in the richness of the soil microbial community, with greater richness $(S)$ in the control having no mine tailings (Table IV). The richness $(\mathrm{S})$ of color change for the mine tailings planted with $P$. notatum 
reached 10-51, representing the richest soil microbial community among the four grasses: P. notatum $>$ F. arundinacea $>$ L. perenne $>$ C. dactylon.

The Shannon index belongs to the first of the three general categories used by Magurran (1988) to group the various diversity measures. It is a useful general diversity index that is influenced by both richness and evenness and is more sensitive to the changes in the abundance of the rare groups. In this study, the Shannon index was a relative index of the functional diversity for the soil microbial community. Table IV shows that for each forage grass, an increase in the percentage of the mine tailings (Treatments A-D) significantly $(P \leq 0.05)$ decreased the Shannon index. The order was the same as for the richness index: $P$. notatum $\geq F$. arundinacea $>L$. perenne $>C$. dactylon. Thus, P. notatum was the grass species that was least sensitive to heavy metal contamination from different ratios of mine tailings, indicating that this grass could improve the soil microbial ecological function for the remediation of areas with mine tailings.

\section{CONCLUSIONS}

All the four forage grasses survived on both the mine tailings and the mixed substrates containing soil, but their biomass decreased with increasing level of soil heavy metals in all treatments. Heavy metal concentrations in the grasses followed the order: $\mathrm{Zn}>\mathrm{Pb}>\mathrm{Cu}>\mathrm{Cd}$. Furthermore, planting of forage grasses, especially $P$. notatum, increased the soil microbial biomass and enhanced the metabolic profiles and the functional diversity of the soil microbial community. Thus, $P$. notatum may be potentially useful as a pioneer forage grass for the restoration of vegetation in abandoned mining areas. However, it must be noted that the above research results were observed in a pot experiment only and long-term field experiments using $P$. notatum to remediate soils contaminated with mine tailings should be conducted in future.

\section{REFERENCES}

Bremner, J. M. and Mulvaney, C. S. 1982. Total nitrogen. In Page, T., Miller, R. H. and Keeney, D. R. (eds.) Methods of Soil Analysis. Soil Science Society of America, Madison, WI. pp. 595-662.

Campbell, C. D., Grayston, S. J. and Hirst, D. J. 1997. Use of rhizosphere carbon sources in sole carbon source tests to discriminate soil microbial communities. Journal of Microbiological Methods. 30(1): 33-41.

Chander, K. and Brookes, P. C. 1993. Residual effects of zinc, copper and nickel in sewage-sludge on microbial biomass in a sandy loam. Soil Biology and Biochemistry. 25(9): 1231-1239.

Doelman, P., Jansen, E., Michels, M. and van Til, M. 1994. Effects of heavy metals in soil on microbial diversity and activity as shown by the sensitivity-resistance index, an ecologically relevant parameter. Biology and Fertility of Soils. 17: $177-184$.

Garland, J. L. 1997. Analysis and interpretation of community-level physiological profiles in microbial ecology. FEMS Microbiology Ecology. 24(4): 289-300.

Jung, M. C. and Thornton, I. 1996. Heavy metal contamination of soils and plants in the vicinity of a lead-zinc mine, Korea. Applied Geochemistry. 11(1): 53-59.

Lan, C. Y. and Shu, W. S. 1996. Amelioration of soil media during vegetative rehabilitation in the mining wasteland. Chinese Journal of Ecology (in Chinese). 15(2): 55-59.

Lan, C. Y., Shu, W. S. and Wong, M. H. 1998. Reclamation of Pb/Zn mine tailings at Shaoguan, Guangdong Province, Peoples' Republic of China: The role of river sediment and domestic refuse. Bioresource Technology. 65(1): 117-124.

Liu, H. Y., Probst, A. and Liao, B. H. 2005. Metal contamination of soils and crops affected by the Chenzhou lead/zinc mine spill (Hunan, China). Science of the Total Environment. 339(1): 153-166.

Long, J., Huang, C. Y., Teng, Y. and Yao, H. Y. 2003. Effects of copper tailings on the growth status of five forage grasses. Grassland of China (in Chinese). 25(2): 18-21.

Lu, R. K. 1999. Analytical Methods of Soils and Agricultural Chemistry (in Chinese). China Agricultural Science and Technology Press, Beijing. pp. 107-240.

Magurran, A. E. 1988. Ecological Diversity and Its Measurement. Princeton University Press, Princeton. pp. $34-59$.

Martin, J. K. and Merckx, R. 1992. The partitioning of photosynthetically fixed carbon within the rhizosphere of mature wheat. Soil Biology and Biochemistry. 24(11): 1147-1 156.

Nelson, D. W. and Sommers, L. E. 1982. Total carbon, organic carbon and organic matter. In Page, A. L., Miller, R. H. and Keeney, D. R. (eds.) Methods of Soil Analysis. Soil Science Society of America, Madison, WI. pp. 539-577. 
Tu, C., Zheng, C. R. and Chen, H. M. 2000. The current status of soil-plant system in copper mine tailings. Acta Pedologica Sinica (in Chinese). 37(2): 284-287.

Vance, E. D., Brookes, P. C. and Jenkinson, D. S. 1987. An extraction method for measuring soil microbial biomass-C. Soil Biology and Biochemistry. 19(6): 703-707.

Wong, M. H. 2003. Ecological restoration of mine degraded soils, with emphasis on metal contaminated soils. Chemosphere. 50(6): $775-780$

Xia, H. P. and Shu, W. S. 2001. Resistance to and uptake of heavy metals by Vetiveria zizaniodes and Paspalum notatum from lead/zinc mine tailings. Acta Ecologica Sinica (in Chinese). 21(7): 1121-1 129

Yao, H. Y., He, Z. L., Wilson, M. J. and Campbell, C. D. 2000. Microbial biomass and community structure in a sequence of soils with increasing fertility and changing land use. Microbial Ecology. 40: 223-237.

Yao, H. Y., Xu, J. M. and Huang, C. Y. 2003. Substrate utilization pattern, biomass and activity of microbial communities in a sequence of heavy metal-polluted paddy soils. Geoderma. 115(1): 139-148.

Ye, Z. H., Shu, W. S., Zhang, Z. Q., Lan, C. Y. and Wong, M. H. 2002. Evaluation of major constraints to revegetation of lead/zinc mine tailings using bioassay techniques. Chemosphere. 47(10): 1103-1111.

Zhang, Y. X. and Cai, T. Y. 1999. Research advances on the mechanisms of heavy metal tolerance in plants. Acta Botanica Sinica (in Chinese). 41(5): 453-457.

Zhang, Z. Q., Shu, W. S., Lan, C. Y. and Wong, M. H. 2001. Soil seed bank as an input of seed source in revegetation of lead/zinc mine tailings. Restoration Ecology. 9(4): 378-385.

Zhao, J. 2006. Biological monitoring and assessment of soil health. Soils (in Chinese). 38(2): 136-142.

Zhou, D. M., Wang, Y. J. and Chen, H. M. 2002. Primary study of distribution of heavy metals in copper mines. Agro-Environmental Protection (in Chinese). 21(3): 225-227. 